\title{
The effect of R\&D subsidies and tax incentives on employment: an evaluation for small firms in France
}

\author{
Vincent Dortet-Bernadet * et Michaël Sicsic **
}

\begin{abstract}
Between 2003 and 2010, the amount of tax incentives and subsidies granted by French public authorities to finance the R\&D activities of SMEs increased fourfold. This very sharp increase is due to the research tax credit (RTC) reforms, particularly in 2008, the creation in 2004 of a young innovative business status and an increase in subsidies over the period. Based on exhaustive employment data for France, this paper presents the first ever evaluation of the effect of the increase in these aids on small firms.

Using a method that combines matching and a labour demand model, we show that the effect of public support on R\&D employment is positive and increased during the period 2004-2010. Nonetheless, the increase in aid, particularly subsequent to the wide ranging reform of the RTC in 2008, was accompanied by a significant crowding-out effect: according to our estimates, only between 18 and 34\% of the supplementary aid obtained by businesses between 2008 and 2010 was used to finance new jobs for highly qualified workers.
\end{abstract}

JEL codes: O38, H25, C33, C36

Keywords: R\&D subsidies, $R \& D$ tax incentives, public policy evaluation, matching, labour demand model

Reminder:

The opinions and analyses in this article are those of the author(s) and do not necessarily reflect their institution's or Insee's views.
*Insee (vincent.dortet-bernadet@insee.fr).

** Insee et Cred, Université Panthéon-Assas Paris II (sicsic.michael@gmail.com).

The authors would like to thank Louis de Gimel, Claire Lelarge, Corinne Prost, Loriane Py, Fabienne Rosenwald, Frédérique Sachwald, three anonymous referees, as well as the participants at Insee's D2E seminars, AFSE/DG Treasury's public policy evaluation, and Cred's Working Group on fiscal economy. The authors would also like to thank the Directorate General for Research and Innovation at the Ministry for Education, Higher Education and Research for allowing them to use the research credit management database. The authors are sole responsible for any error or omission in this document. 
$\mathbf{R}$ esearch and development (R\&D) activities are designed to promote the emergence of new manufacturing materials, products or processes and improvements to them. Stimulating innovation and technical progress, $R \& D$ is an important source of economic growth (Griffith et al., 2003; 2004). In France, the ratio of domestic business expenditure on $R \& D$ (BERD $)^{1}$ remains quite weak compared to other major countries: $1.45 \%$ of GDP in 2014 compared to $1.6 \%$ for OECD countries, almost $2 \%$ in Germany and $2.8 \%$ in Japan (OECD, 2017). Nonetheless, during the 2000s, public authorities significantly developed support schemes in order to boost private R\&D expenditure. The State allocated to firms some 8 billion Euro in financial support to R\&D in 2013, i.e. close to $0.4 \%$ of GDP (compared to less than $0.2 \%$ in 2003). In 2013, France was the 3rd biggest public funder of R\&D in the world and the leading country in terms of tax incentives for R\&D (OECD, 2016).

This paper studies the impact on employment of the significant increase in public support to $R \& D$ received by small businesses during the period 2004-2010. Small firms have, for example, benefited from the creation in 2004 of the "Young innovative business" status (Jeune Entreprise Innovante, JEI) for firms younger than eight years old and specialised in R\&D activities. More significantly, the various research tax credit (RTC) reforms from 2004 onwards, and particularly in 2008, allowed for a significant increase in the number of small companies benefiting from this scheme. Lastly, small firms have also been given the opportunity to receive subsidies from Oséo $^{2}$, a body set up in 2005 to support innovation projects undertaken by small and medium enterprises (SMEs).

Few studies have focused on evaluating the effect of R\&D public support received by small businesses. These firms, nevertheless, receive the highest support rates: in 2010, $50 \%$ of $R \& D$ expenditure declared by very small

1. Gross domestic expenditure on research and development (GERD) corresponds to the research and development (R\&D) activity performed on the national territory regardless of the funding source. Some of this activity is performed by public administrations, while the rest is carried out by firms (Business expenditure on research and development, BERD). This includes current expenditure (wage bill of $R \& D$ staff and operating costs) and capital expenditure (purchase of equipment needed for domestic $R \& D$ activity and real estate transactions completed over the course of the year).

2. Oséo was set up in 2005, bringing together the Anvar, BDPME and Sofaris, and was then incorporated into BPIFrance in 2013. businesses $^{3}$ (VSBs) benefiting from RCT was funded through aid compared to $42 \%$ for other SMEs, $36 \%$ for intermediate-sized enterprises (Entreprises de Taille Intermédiaire, ETI) and $34 \%$ for the biggest firms (Dortet-Bernadet \& Sicsic, 2015, p. 15).

\section{Why help small firms to perform R\&D?}

Public support for firms to fund their R\&D expenditure is justified by the fact that, without this aid, they would tend to perform less R\&D than the level desirable for the whole economy (Jones \& Williams, 1998; Bloom et al., 2013). By reducing the private cost of $R \& D$ activities, public funding is likely to increase R\&D expenditure to a socially optimal level. Providing specific support to small and young firms can be justified by the fact that these firms are more affected by financing restrictions than other firms. These restrictions would give rise to excessively low R\&D investments with procyclical evolutions ${ }^{4}$ (Aghion et al., 2012). Financial public support can also help small firms that would otherwise not have undertaken R\&D activities (González et al., 2005).

Helping the youngest businesses can also be effective, as it is argued that these firms are behind breakthrough innovations (Schneider \& Veugelers, 2010; Cincera \& Veugelers, 2012; Akcigit \& Kerr, 2010). Based on simulations using a theoretical model, Acemoglu et al. (2013) find that it would be more effective to subsidise firms entering the market (especially young and small firms) to undertake $R \& D$ than already established firms. However, it should be noted that, in an empirical analysis, Garcia-Macia et al. (2016) find that most of the growth in productivity does not come from young businesses, but rather from improvements to the products of incumbents.

Although public support for R\&D can serve to boost private funding of $R \& D$ (amplifying effect of aid), it can also simply have an additive effect, or even be a substitute for privately funded R\&D (deadweight loss or crowding-out effect) (David et al., 2000). In this latter case, the firms use the public funds to finance projects that they would have performed anyway, even without public support.

\footnotetext{
3. See Box 2 for the definition of the categories of companies. 4. R\&D as a share of investments is said to fall during periods of recession and it is argued that this fall is not fully offset during periods of economic recovery.
} 


\section{Differing results relating to the effect of $R \& D$ depending on the size of the company}

There is a significant body of literature on evaluations of the impact of public support to business R\&D (Ientile \& Mairesse, 2009; Kohler et al., 2012; Zuñiga-Vicente et al., 2014, for literature reviews). It points to the differing results of research into the effectiveness of R\&D aid received by small firms. Some of these differences can be attributed to the variety of support schemes in place in the various countries of the OECD. For example, for Busom et al. (2014), young Spanish businesses without any experience of $R \& D$ mainly use subsidies and tax credit schemes are less suited to firms embarking on an R\&D activity. In Spain once again, Corchuelo and Martinez-Ros (2009) demonstrate that tax incentives to perform R\&D are more effective for large firms than for SMEs. However, according to Lokshin and Mohnen (2012), who examined a tax credit scheme proportionate to expenditure volumes in the Netherlands, tax incentives are particularly effective for small firms, the only category of firms where crowding-out effects do not come into play. Hægeland and Møen (2007) reach a similar conclusion for tax credits in Norway. However, like Lokshin and Mohnen (2013), they also show that support has a significant effect on the increase in salaries paid to researchers. In Italy, Bronzini and Iachini (2014) have highlighted the additive effect of an R\&D subsidy programme for small businesses, but not for large firms. Finally, based on an existing system in Québec, Baghana and Mohnen (2009) point to the fact that a tax credit that is proportional to the volumes of $R \& D$ expenditure is not effective for large firms, but is for small businesses: for the latter, the increase in R\&D expenditure outstrips the amount of financial support.

\section{Studies based on French data use partial data relating to small businesses}

In France, evaluations are mostly based on data from the R\&D Survey conducted by the Ministry for Education, Higher Education and Research (MENESR). This survey provides very detailed information about the expenditure of major producers of R\&D. However, it only partially covers the population of young or small firms and its changing coverage makes it difficult to use only this survey to evaluate the impact of $R \& D$ public support on small firms (Box 1). Research conducted to assess the effectiveness of $R \& D$ support using the data from this survey has thus focused on medium-sized and large enterprises. It is mostly the research tax credit (RTC) that has been evaluated: amongst the most recent research, we can cite Duguet (2012), Mulkay and Mairesse (2013), Bozio et al. (2015). These evaluations reach the overall conclusion that RTC has an additive effect or a slight amplifying effect. Duguet (2004) obtains a similar result for direct financial support paid out over the period 1985-1997. Lhuillery et al. (2013)

Box 1

\section{THE R\&D SURVEY: PARTIAL COVERAGE OF SMALL FIRMS AND CHANGES DURING THE 2000s}

Evaluating the effectiveness of R\&D financial public support for small firms based solely on the MENESR's R\&D Survey poses statistical difficulties: the survey only provides partial and changing information about young and small firms.

Firstly, the survey only partially covers the population of small firms receiving indirect financial support (tax credits and tax breaks). Indeed, using only the survey sample and weightings leads to systematically underestimating the amount of indirect aid received by small firms. For example, between 2003 and 2010, it only covered $61 \%$ of the amount of research tax credits (RTC) received by very small firms (see online complement C1).

Secondly, the survey provides fairly unrealistic estimations of the change in R\&D expenditure by small firms, as its coverage changed over the course of the 2000s. As the survey database is updated based on the lists of firms applying for aid, the increasing number of SME's benefiting from the RTC automatically expanded the coverage of the survey, which gave rise to very volatile estimations of changing levels of $R \& D$ employment: $-18 \%$ in $2005,+40 \%$ in $2006,-10 \%$ in $2007,+22 \%$ in 2008 .

The survey is also not well suited to individual monitoring of the R\&D expenditure of the smallest firms in the panel. The youngest (under two years old) and the smallest firms have a very low probability of being surveyed over two consecutive years (Bellégo \& DortetBernadet, 2014). The survey is not designed either to observing firms that are just starting an R\&D activity, as the updating of the database only takes account of the firms that have already carried out R\&D. 
point broadly to the additive effect of subsidies and research tax credits, but they also observe crowding-out effects for firms that receive low or moderate levels of support 5 .

Studies that exclude the largest firms from their coverage arrive at more mixed results. According to Serrano-Velarde (2008), obtaining subsidies from Anvar is accompanied by a fall in private R\&D expenditure (R\&D net of aid) among SMEs and intermediate-sized enterprises that have received support. However, within a comparable coverage, Bellégo and Dortet-Bernadet (2014) show that the supplementary public funding received for being involved in competitive clusters' did not lead to a reduction in private expenditure. Nonetheless, these two studies were based on the R\&D Survey, which excludes the smallest companies. Lelarge (2009), who does not use solely the R\&D Survey, but also data similar to ours, shows that during the early years of the JEI scheme (2004-2005), firms increased

5. They also show that the most effective aid is either very low or very high levels of aid. the wages paid out, which enabled them to retain their most qualified staff.

\section{Studying the effect of R\&D public funding using exhaustive employment data}

In order to avoid the difficulties associated with using the R\&D Survey for small firms (Box 1), we propose studying only part of the R\&D expenditure: that relating to $R \& D$ jobs. We evaluate the effect of R\&D public support on the employment of highly qualified staff ${ }^{6}$, for which exhaustive data are available through the Déclarations annuelles de données sociales (DADS annual declarations submitted by employers, Box 2). The effect of support on the employment of $\mathrm{R} \& \mathrm{D}$ personnel is then deduced from this.

Only the effect of the total amount of support is studied: although this option does not allow for

6. Defined as total employment in the categories of senior mana-
gers, higher intellectual professions and company managers gers, higher intellectual professions and com
(professional categories 2 and 3 in the DADS).

Box 2

\section{DATA}

Data relating to $R \& D$ employment and public funding of $R \& D$

Several databases are used in this study in order to measure the amounts of financial support received by the firms and to estimate the number of R\&D-related jobs:

- The database used to manage research tax credits (GECIR, source: MENESR). In addition to the amount of the tax credit, this database provides information about all of the subsidies received by the firms in order to finance their R\&D activities.

- The register of participants in the "Young Innovative Business" scheme (JEl, for Jeunes Entreprises Innovantes) (source: Acoss). This register provides the total amount of exemptions from employer payroll taxes granted to the participating firms. Tax exemptions (of the research tax credit type) are not taken into account, but they only represent $10 \%$ of the total amount in 2010 .

- The list of MENESR accreditations (source: MENESR). An accredited firm performs R\&D for other firms, which are thus entitled to benefit from the RTC.

- The R\&D survey database (source: MENESR): the survey is used to measure the amount of direct support and estimate the number of R\&D jobs between 2008 and 2010.

\section{Other sources of information}

In order to reconstruct categories of firms and to estimate the number of R\&D posts, various Insee databases are used: tax data (Ficus/Ésane, Insee), the Déclarations de données sociales (DADS - annual declarations submitted by employers), the database of financial ties (Lifi) and the national register of enterprises and establishments (Sirene, Insee). It should be noted that the figures related to turnover, valued added, wages and aid are deflated using the value-added price index for each branch of activity (based on a reference date of July 2000).

The DADS provide an exhaustive description of salaried employment situations by professional category. Staff levels by professional category were recalculated in 2009 and 2010 in order to control the influence of a change in the method of coding professional categories. The labour cost has been estimated based on gross wages, to which have been added estimations of the levels of employer payroll taxes as proposed by Cottet et al. (2012).

The study covers small and medium enterprises (SMEs), as well as very small businesses (VSBs); the former count less than 250 employees, do not have an annual turnover in excess of 50 million Euro or a total balance sheet that does not exceed 43 million Euro; the latter have less than 10 employees, an annual turnover or a total balance sheet of 2 million Euros at most (see definition in Béguin et al., 2012). 'Firms' relate solely to independent legal entities or groups: legal entities belonging to large groups were excluded from the coverage of the study. 
a comparison of the respective merits of each R\&D support scheme, it does allow for the study of the large number of cases where firms make use of several support schemes simultaneously ${ }^{7}$. In order to estimate the amount of R\&D support received by small firms, we use lists of firms benefiting from indirect support mechanisms (RTC and JEI scheme), as well as the R\&D Survey, which allows us to take account of direct regional, national and European support (Box 2).

The paper is structured as follows: In the first section, we recall the main developments in the R\&D public support to SMEs during the period 2003-2010. We then estimate the aggregated changes in employment levels in the field of R\&D and we show that, for SMEs, employment not financed by public support has fallen significantly. In the second section, we restrict the focus to small firms from R\&D-intensive sectors and evaluate the effect of the R\&D support on employment for the years 2004-2010, based on a panel of firms that received aid or did not receive aid. The results indicate that public funding had positive effects on the employment of highly qualified staff (and R\&D staff), but there were also windfall effects, particularly by the end of the period.

\section{Aggregated changes in R\&D public funding and $R \& D$-related employment during the period 2003-2010}

\section{Changes in the $R \& D$ support schemes used by SMEs}

R\&D support schemes include indirect and direct aids. Indirect aid primarily include the

7. In 2010 , over $80 \%$ of the companies that received a direct aid also benefited from an indirect support.
RTC and reductions in employer payroll social contributions that are part of the JEI status, while direct subsidies are allocated by various bodies responsible for promoting $R \& D$ in firms.

The RTC is a tax break granted to firms of all sizes that perform R\&D. Between 1983 and 2003, the mechanism basically kept the same structure: the amount of the tax credit depended on the increase in R\&D expenditure from one year to the next and was capped at a certain amount (MENESR, 2014). The first major reform of the RTC took place in 2004 when a supplementary tax credit share was introduced based on the volume of R\&D expenditure. This represented $5 \%$ of expenditure in 2004 and 2005 , and then $10 \%$ in 2006 . The tax credit calculated on the basis of the increase in this expenditure was, however, reduced gradually (Table 1) and the tax credit cap was increased to 16 million Euro in 2007.

The reform of the RTC in 2008 abolished the tax credit based on the increase in $R \& D$ expenditure, increased the rate applicable to the expenditure volume to $30 \%$ for amounts up to 100 million Euro, then 5\% above this amount, and abolished the cap on the amount of the tax credit. Higher rates have also been applied to firms applying for the first time for the RTC (a rate of $50 \%$ for the first year and $40 \%$ for the second).

Following the successive reforms of the RTC, the amount of this aid increased eleven-fold between 2003 and 2010, reaching 5 billion Euro.

The JEI status created in 2004 entitles SMEs that are less than 8 years old and whose R\&D activities account for at least $15 \%$ of their charges to pay lower employer payroll contributions. The total amount of support linked to the JEI status is much lower than for the CIR (some 140 million Euro in 2010), but doubled

Table 1

Changes to the parameters of the research tax credit (RTC) between 2003 and 2010

\begin{tabular}{|l|c|c|c|c|c|}
\hline & from 1991 to 2003 & $2004-2005$ & 2006 & 2007 & From 2008 to 2010 \\
\hline Rate (\%) volume-based & & & & & $\begin{array}{c}30 \% \text { up to } 100 \text { million Euro } \\
5 \% \text { above } 100 \text { million Euro } \\
\text { Higher rates }\end{array}$ \\
Rate (\%) increment-based & 50 & 5 & 10 & 10 & $\begin{array}{c}50 \% \text { for the } 1^{\text {st }} \text { year and } \\
40 \% \text { for the } 2^{\text {nd }} \text { year (*) }\end{array}$ \\
Cap (in millions of Euro) & 6.1 & 8 & 40 & 40 & /l/ \\
\hline
\end{tabular}

(*) For firms applying to RTC for the $1^{\text {st }}$ time

Source: based on MENESR documents 
between 2004 and 2010. Moreover, for VSBs, it amounts to around $20 \%$ of all indirect subsidies.

Direct public aids are subsidies aimed at specific projects or covering a specific type of expenditure. These subsidies include refundable advances (refunds depend on the success of the project receiving support), premiums, subsidised loans, guarantees and public procurement orders. They are granted by local authorities, various national bodies, such as Oséo or the Fonds unique ministériel (FUI) ${ }^{8}$, or by the European Union ${ }^{9}$. As of 2005, Oséo-Innovation was specifically charged with financing R\&D performed by SMEs. Direct aids increased in total by $64 \%$ for SMEs between 2003 and 2010 , whereas they remained stable for intermediate-size and large firms (Dortet-Bernadet \& Sicsic, 2015).

Finally, the total amount of (direct and indirect) support to $R \& D$ received by SMEs increased by $300 \%$ between 2003 and 2010, reaching nearly 2 billion Euro, 26\% of which, or some 500 million Euro, was received by VSBs (Dortet-Bernadet \& Sicsic, 2015).

\section{Aggregated estimation of changes in R\&D employment in SMEs not financed by public funding}

In this section, we present a three-stage estimation of changes between 2003 and 2010 in total R\&D-related employment (hereafter referred to as R\&D employment) in SMEs and the amount of support received to fund it. We first estimate the change in expenditure on R\&D employment in SMEs (stage 1), and then the change in support for R\&D spent on employment (stage 2). Lastly, in the 3rd stage, we compare these two results in order to estimate the change in the numbers of R\&D jobs that have not been funded by public support.

\section{Stage 1: estimation of $R \& D$ employment}

To estimate the change in R\&D employment, we make a two-step calculation. Firstly, we calculate this employment in SMEs (including VSBs) during the period 2008-2010 using data

8. For example, for projects conducted within the framework of competitive clusters (Dufau, 2017 ; Bellégo \& Dortet-Bernadet, 2014).

9. Financing can be secured under the Framework Programme for Research and Technological Development or the European Regional Development Fund. from the R\&D survey, the Gecir database ${ }^{10}$, the list of JEI, and the list of MENESR accreditations (see Box 2). We work on the assumption that, for the period 2008-2010, the development of public support to R\&D enables us to obtain an almost exhaustive list of SMEs that undertake R\&D activities. We then calculate the change in $R \& D$ employment for the period 2003-2010 based on the assumption that, for each sector (level 5 of the French classification of activities, NAF) and category of firm, the ratio $^{11}$ of the number of R\&D jobs to the number of 'highly-qualified' jobs ( $H Q$ jobs $_{t}^{\text {sector, size }}$, source: $D A D S$ ) is stable over time:

$$
\begin{aligned}
& \text { Estimated } R \& D \text { jobs }_{t}^{\text {sector, size }}= \\
& \frac{R \& D \text { jobs }_{2008-2010}^{\text {sector, size }}}{H Q \text { jobs }_{2008-2010}^{\text {sector,size }}} \times H Q \text { jobs }_{t}^{\text {sector, size }}
\end{aligned}
$$

This assumption of stability may appear to be a strong one, as this ratio may have increased as the support for R\&D increased. However, a calculation based on the European innovation Survey shows that the ratio of firms domestic expenditure on R\&D (BERD) to expenditure on highly qualified employment remained broadly stable for SMEs, excluding VSBs, between 2004 and 2008 (falling from 11\% to 9\%).

According to our estimations, R\&D employment in SMEs (excluding VSBs) increased more than R\&D employment in VSB between 2003 and 2008 and the 2008/2009 crisis had a greater impact on the latter (Figure I). Expenditure on R\&D employment follows a similar trend. Nonetheless, unlike with R\&D employment levels, expenditure on R\&D employment in VSBs did not fall between 2003 and 2010: it increased by $5 \%$ (16\% for other SMEs). These trends are very different from those obtained on the basis of the R\&D Survey, but they seem more realistic (see discussion in the online complement $\mathrm{C} 1$ ).

Stage 2: estimation of public funding used to finance $R \& D$ jobs

To estimate the amount of public support used to finance R\&D employment, different rules are applied depending on the support scheme. For

10. We take the amount of expenditure on $R \& D$ staff recorded in the database divided by the mean labour cost of an engineer (source: DADS).

11. Only part of highly-qualified jobs are allocated to $R \& D$ but, for the SMEs that responded to the R\&D Survey, we get a correlation of $62 \%$ between real R\&D employment and the estimation made using our method and a correlation of $72 \%$ for the companies in the panel used in the last section of the paper. 
Figure I

Evolution of R\&D employment and expenditure on R\&D employment
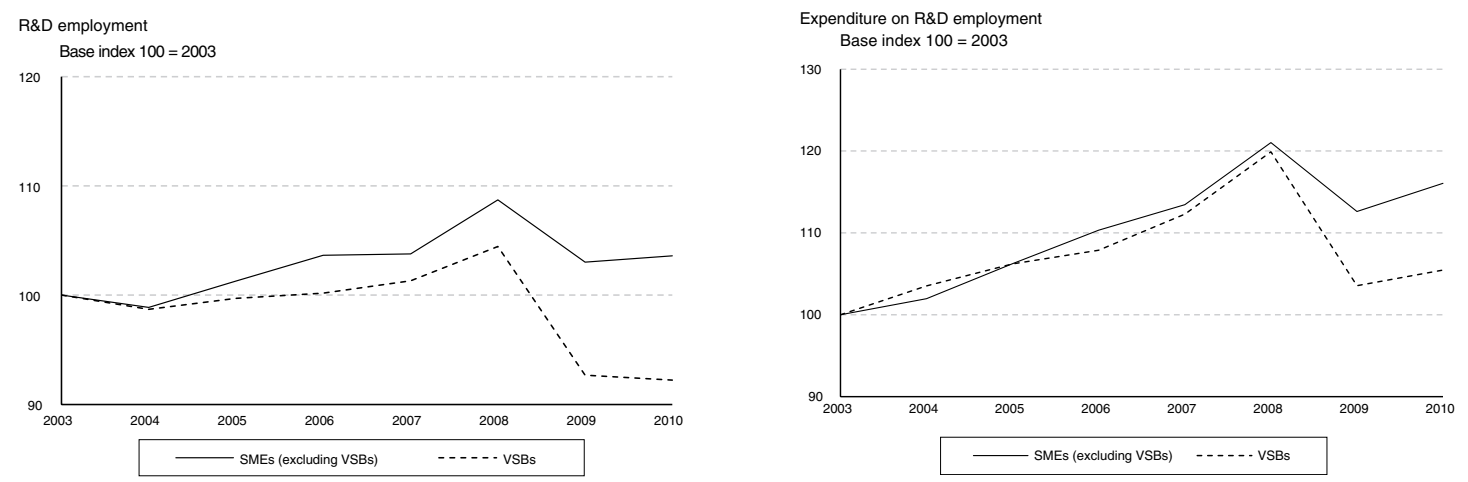

Reading note: between 2003 and 2010, R\&D-related employment fell by $8 \%$ in VSBs, and rose by $4 \%$ in other SMEs. R\&D-related employment expenditure rose by $5 \%$ in VSBs and by $16 \%$ in other SMEs.

Coverage: France, trade, manufacturing and market services.

Source: MENESR, GECIR database, R\&D Survey; Acoss, JEl database; Insee, Lifi, Ficus/Ésane, DADS. Authors' calculations.

JEIs, the exemptions from employer payroll contributions are entirely considered in their entirety as aid for R\&D employment. The share of the RTC that serves to finance employment corresponds to the share of staff and operating expenditure in the RTC tax base. To calculate the CIR tax base, the operating expenditure is set at $75 \%$ of staff expenditure: the resulting tax credit can thus be interpreted as an employment aid.

Unlike with indirect aid, no database provides exhaustive information on direct aids: their amount must be estimated. For each company, the estimation of support used to finance employment is made on the basis of the information reported in the CIR database, supplemented by, where necessary, information from the R\&D Survey. As these sources sometimes differ, the amount of support retained is the highest amount reported by one of these sources.

According to our estimations, $R \& D$ support devoted to employment accounts for around three quarters of R\&D support received by VSBs and other SMEs. Between 2003 and 2010, R\&D public support devoted to employment increased by $280 \%$ in VSBs and $440 \%$ in SMEs, with a particularly large increase in 2008 due to the reform of the RTC (Figure II).

Figure II

\section{Public funding of R\&D employment}

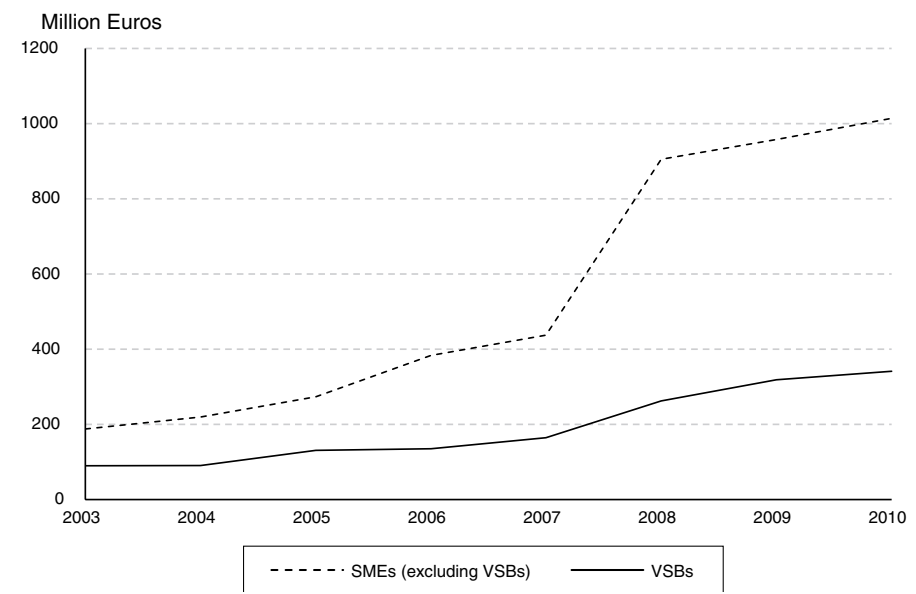

Reading note: in 2010, 341 million Euros and 1.01 billion Euros of R\&D support were devoted to R\&D employment in, respectively, VSBs and the other SMEs.

Coverage: France, trade, manufacturing and market services.

Source: MENESR, GECIR database, R\&D Survey; Acoss, JEl database; Insee, Lifi, Ficus/Ésane, DADS. Authors' calculations. 
Stage 3: change in R\&D employment not financed by public funding

By taking the ratio of the amount of aid (estimated during stage 2) to the mean labour cost of R\&D employment (estimated on the basis of the results of the first stage), we can estimate the amount of R\&D-related employment that is 'funded by public support'. On the basis of the estimation of R\&D employment in the second stage, we can then deduce R\&D employment 'not funded by public support', i.e., the share of R\&D employment that would not have benefited from public funding. According to our estimations, this share fell sharply (by $46 \%$ between 2003 and 2010 for VSBs) and less significantly (-16\% over the same period) for other SMEs (Figure III). For very small firms, the fall was 9\% between 2004 and 2007, followed by a more significant fall in 2008, the year in which the RTC was reformed (fall of $41 \%$ between 2007 and 2010). Overall, considering all SMEs (VSBs included), the fall was around $20 \%$ over the period.

These trends in R\&D employment not funded by public support suggest deadweight effects, particularly from the significant increase in support to R\&D in 2008. Nonetheless, this period was also marked by the financial crisis, which may have had an impact on the employment of researchers by small firms. The size of firms is also likely to have changed over time, including as a result of receiving support. For example, the most dynamic VSBs that received aid may have become SMEs (excluding VSBs), which could explain part of the fall in R\&D employment not financed by aid within the category of VSBs (the same applying to the transition from SME to intermediate-sized enterprise).

\section{Evaluation of the effect of R\&D public funding on employment}

In this section, we seek to evaluate the effect of public funding on R\&D-related employment in small firms. This evaluation monitors small firms, regardless of any changes in their size category, by comparing them to firms that were initially 'similar' and operating in the same economic environment.

To be more precise, the effect of R\&D support on employment is estimated on the basis of a panel of small firms monitored over several years (2003-2010). As in the previous section, any financial public support that can be associated with $\mathrm{R} \& \mathrm{D}$ employment is taken into account.

The firms that receive public funding a given year cannot, however, apply for aid the following year, the effect of the aid already received continuing over time. In order to take this lagged effect into account, the firms 'treated' in any given year include those firms having

Figure III

Evolution of R\&D employment not financed by public funding

Base index $100=2003$

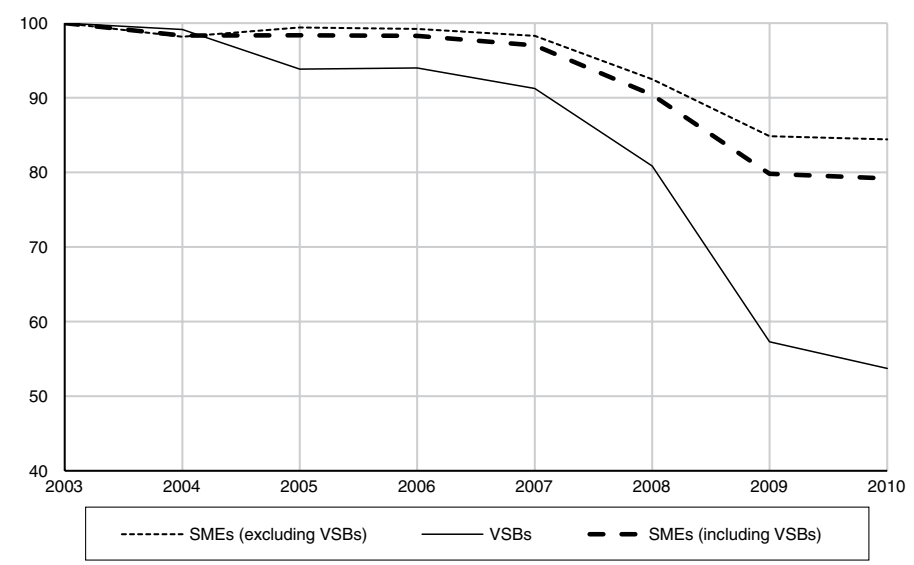

Reading note: R\&D employment 'not funded by public support' in 2003 is the reference (index=100). In 2010, this index reaches 54 for VSBs, i.e. a fall by $46 \%$ compared to 2003 .

Coverage: France, trade, manufacturing and market services.

Source: MENESR, GECIR database, R\&D Survey; Acoss, JEl database; Insee, Lifi, Ficus/Ésane, DADS. Authors' calculations. 
received support that year and those that had already received it during the previous years.

The estimations are obtained first of all for highly qualified employment, then converted into R\&D-related employment using the method presented in the previous section.

\section{Construction of the panel used for the estimations}

The evaluation is made using a panel of small firms from the 75 most highly R\&D-intensive sectors of the economy (Dortet-Bernadet $\&$ Sicsic, 2015, p. 48). These firms are regarded as small because they have all been VSBs for at least one year during the period 2000-2010. They continue to be followed even if they grow and become an SME with 10 or more employees or an intermediate-sized enterprise ${ }^{12}$; however, most of the firms covered remain VSBs. The coverage also includes the large majority of young enterprises.

The coverage of the evaluation is restricted to firms that have highly-qualified staff. We calculate the effect of the support for firms present in 2003 (i.e., those that had highly qualified staff in 2003) and the effect for firms present in $2007^{13}$ : these two reference years were chosen in order to observe the firms prior to the two major reforms of the RTC in 2004 and 2008. The panel is not balanced: some firms ceased

12. In 2010, a third of the firms in the panel were SMEs and $3 \%$ intermediate-sized firms. Some were bought out by large groups, but these cases are very few. As they can give rise to ambiguities about the continuity of the initial activity, they were removed from the databases used to make the estimations.

13. These two treatment groups are not disjointed, as some companies have highly qualified workers in both 2003 and 2007. to exist prior to 2010 or were created after 2003. However, each company must have had highly qualified employees for a period of at least two years (including the reference year, 2003 or 2007).

The panel includes firms that received support and others that did not, but which are similar to those that received it. The firms that never received support were selected on the basis of their age and a propensity score that estimates the probability of a company receiving support at least once between 2004 and 2010 on the basis of different variables (see online complement C2). This model indicates that the support schemes are more frequently used by young enterprises that make investments, export and have a lot of qualified staff. These results seem to be consistent with the idea that support schemes are used more by young, developing firms that do not yet produce very much or nothing at all (turnover has a negative effect and is barely significant). In total, the panel contains 15,128 firms, 4,597 of which received support at least once between 2003 and 2010 (Table 2).

The sectors are grouped together in three main categories: industrial, information and communication (IT, publishing, telecommunications, etc.) and a third category bringing together sectors comprising specialised, scientific and technical activities (R\&D, engineering, etc.). Firms from services sectors form clearly the biggest sector $(79 \%)$. Almost all the firms having received support benefited at least once from the RTC. The sectoral breakdown of subsidised firms is similar to that of firms that benefited from the CIR. A very large share of the firms granted the 'Young innovative business' status (JEI) are IT service firms.

Table 2

R\&D public funding received by the small firms in the panel between 2003 and 2010

\begin{tabular}{|l|c|c|c|c|c|}
\hline Firms that have & $\begin{array}{c}\ldots \text { received R\&D public } \\
\text { support at least once }\end{array}$ & $\begin{array}{c}\ldots \text { benefited } \\
\text { from the RTC }\end{array}$ & $\begin{array}{c}\ldots \text { received } \\
\text { a subsidy }\end{array}$ & $\begin{array}{c}\ldots \text { had JEI } \\
\text { status }\end{array}$ & $\begin{array}{c}\text { Firms that never } \\
\text { received any aid }\end{array}$ \\
\hline Number of firms & 4,597 & 4,064 & 2,334 & 1,348 & 10,531 \\
\hline Breakdown (in \%) & \multicolumn{5}{|l|}{} \\
Industry & 20 & 20 & 19 & 9 & 22 \\
IT services & 42 & 42 & 41 & 55 & 33 \\
Scientific and technical activities & 38 & 38 & 40 & 36 & 46 \\
\hline
\end{tabular}

Reading note: of the panel of 15,128 firms, 4,597 firms received aid at least once between 2003 and 2010, 4,064 benefited from the RTC, 2,334 received a subsidy, 1,348 enjoyed JEl status and 10,531 received no aid.

Coverage: panel comprising small firms present in 2003 and/or 2007 from 75 R\&D-intensive sectors, having received R\&D aid between 2003 and 2010 or which are 'similar' to the firms receiving aid (matched on their propensity score).

Source: MENESR, GECIR database, R\&D Survey; Acoss, JEI database; Insee, Lifi, Ficus/Ésane, DADS. Authors' calculations. 


\section{Identification strategy}

\section{Problems arising from the use of the difference-in-difference method}

The effect of support on employment corresponds to the difference between the number of highly qualified jobs observed in the firms receiving support and the number of jobs there would have been if no aid had been received. To compute this effect, we must consider a fictitious situation where the firms that received support (treated firms) do not receive any support (or supplementary support). This estimation can be made by the difference-in-difference method based on the assumption that, without support, treated firms would have behaved in the same way as those that never received any support (non-treated firms) and which have a similar propensity score (see the results in the online complement C3).

This method gives rise, however, to several difficulties. The first relates to the choice of the control group. Indeed, the assumption of common trend for the treated and non-treated firms is not respected: before even receiving initial support, employment was more dynamic in the firms that received aid than in those never having received it. The firms that have not yet received support are then a more satisfactory control group: firms that received support as early as year $t$ and those that only receive aid after $t$ show similar trends in terms of highly-qualified employment through to $t-1^{14}$.

The second difficulty relates to the interpretation of the 'treatment' received by each generation of firms receiving aid. The simple difference-in-difference method does not allow us to account for the heterogenity within each generation of firms receiving support in terms of the amount received and the changes in the support rate.

Lastly, the simple difference-in-difference method does not allow us to take into account the firms having received support as of the reference year (or earlier) taking account of the amounts already received at that time.

14. By using as the control group the generation of companies that only received support as of 2010, we obtain a negative effect of support on highly qualified employment not financed by aid as of 2008 (online complement C3, Tables C3-4 and C3-5).

\section{An evaluation method combining labour demand and matching models}

In order to overcome these various problems, we add all the firms that have not yet received support, but are going to receive some before the end of 2010 to the control group, and we estimate a labour demand model. This model allows us to calculate a level of employment based on the labour cost minus support (considered as a labour cost reduction) and the turnover. This allows us to compare between treated and non-treated firms not in terms of changes in employment levels but in terms of changes in the labour cost and the turnover, for which the assumption of common trend is better verified ${ }^{15}$.

Using the labour demand model, where the demand for labour depends on its cost, also enables us to control for the initial amount of aid received and, therefore, to take account satisfactorily of all the firms receiving aid rather than just those that receive their first lot of aid after the reference year (2003 or 2007). We thus obtain results on the extensive margin (effect on the new firms receiving aid) and on the intensive margin (increase in the rate of aid).

\section{The labour demand model for highly qualified labour}

The labour demand model for highly qualified labour $\left(l_{i t}{ }^{16}\right)$ that is used is derived from a business costs minimisation programme with a Cobb-Douglas-type production function, close to the model presented in the paper by Bresson et al. (1992). It assumes that firms choose their level of highly qualified labour based on their turnover $\left(y_{i t}\right)$ and the relative mean cost of the highly-qualified labour $\left(c_{i t}\right)$ compared to other forms of labour.

The model is estimated only for firms receiving support. For these firms, support is equivalent to a reduction in the cost of highly qualified labour (rather than just the cost of R\&D-related

15. Before receiving their first support at time $t$, the companies resemble the companies that have not yet received any support: they experience similar changes in the labour cost of highly-qualified staff and the turnover. For the companies that have never received any aid, the cost of labour is subject to similar changes, but the turnover remains less dynamic (online complement C4).

16. All non-dichotomous variables mentioned in the model definition are expressed in logs. 
jobs ${ }^{17}$ ) : the cost of labour considered here is a final cost after deducting the amount of R\&D aid $^{18}$. The model takes account of the lagged adjustment in firms' demand for labour and is expressed in the form of a autoregressive model:

$$
\begin{aligned}
l_{i t} & =\rho \cdot l_{i t-1}+\alpha_{1} \cdot y_{i t}+\alpha_{2} \cdot y_{i t-1} \\
& +\beta \cdot c_{i t}+\mu_{i}+\delta_{t}+\varepsilon_{i t}
\end{aligned}
$$

where the level of highly qualified employment at time $t$ depends on the level achieved the previous year, the turnover at $t$ and $t-1$ and the final relative mean cost of labour at $t$.

Highly qualified labour is diverse in nature: it includes jobs devoted to R\&D and jobs with no link to this type of activity. Bresson et al. (1992) recommend, in the event of diverse labour forms, to supplement the model by adding the cost variable measured at $t-1$, but this variable was not used here as it turned out to be too correlated to the cost at $t$ and not significant ${ }^{19}$.

17. In the case of small firms, this assumption appears to be fairly realistic because senior managers that do $R \& D$ only devote part of their working time to this. The fact that many small firms use R\&D aid intermittently (between 2004 and 2010, around 25\% of the VSBs receiving aid one year were no longer doing so in the next year) makes this likely, as it seems to indicate that these firms do not do $R \& D$ every year.

18. For some firms (especially those having obtained subsidies for a multi-annual project), the amount of support received may exceed the total cost of labour. In this case, the labour cost is cancelled out and the excess support is carried over to bring down the cost in the following year.

19. The model should also include a term to measure the cost of highly qualified labour relative to the capital. The cost of capital is difficult to evaluate: it can be approached by using different interest rates, which vary depending on the firms' level of debt. However, the firms covered differ little in terms of their debt level and the estimated values for the cost of capital are too homogeneous to be used for the estimation.
Unobserved heterogeneity of firms is taken into account by introducing a fixed effect $\left(\mu_{i}\right)$ specific to each firm: the autoregressive model then enables us to take account of the heterogeneity of changes in employment (rather than the employment levels). Time-related effects $\left(\delta_{t}\right)$ were added for each year of observation. Moreover, different models have been estimated depending on the classification of the firms in one of the three major types of activity (industry, IT services and scientific and technical activities).

\section{Model estimation}

To estimate the model, we take account of the endogeneity of the relative cost of highly qualified labour. At least two arguments back up this assumption. Firstly, bodies in charge of direct support allocate their grants based on the dynamism of the firms or the innovative dimension of their activities. These two unobserved characteristics explain the growth in employment within firms but, as they dictate the granting of support, they are also correlated to the reduction in the relative cost of labour. Secondly, during the period 2003-2007, the RTC was still partially calculated based on the increase in R\&D expenditure, which implies endogenous changes in the costs of labour.

In order to correct the endogeneity of the relative cost of labour (see the test in the online complement C4, Table C4-2), an instrumental variable is developed on the basis of the different

Box 3

\section{COMPUTATION OF THE INSTRUMENT USED TO CORRECT LABOUR COST ENDOGENEITY}

The change in the relative cost of highly qualified labour after R\&D support $\left(c_{i t}\right)$ can be decomposed based on the change in the rate of support $(\tau)$ and the change in the relative labour cost before deducing support $\left(c_{\text {it }}{ }^{*}\right)$. Based on the assumption that the change in the rate of aid has no bearing (in the short term) on the share of highly qualified employment $\left(d_{i}\right)$ devoted to R\&D, we obtain the following decomposition:

$$
\Delta c_{i t} \approx d_{i} \cdot \Delta \log \left(1-\tau_{i t}^{a i d}\right)+\Delta c_{i t}^{*} .
$$

This decomposition enables us to find an instrument that is correlated to the change in the relative labour cost by replacing each term with an exogenous variable:

- For the term $\Delta \log \left(1-\tau_{i t}^{\text {aid }}\right)$, we use the different reforms of the RTC in 2004, 2006 and 2008, which correspond to exogenous variations in the support rate (16 rate variations are used over the period 20042010, see Table C4-1 of the online complement C4).

- To determine R\&D employment as a share of highly qualified employment $(d)$, the estimations are based on the characteristics of firms prior to the different reforms of the RTC in order not to take account of any modifications (increase in the share of $R \& D$ ) due to the increase in the support rates.

- The variable $\Delta c_{i t}^{*}$ is simply replaced by the lagged variable $\Delta c_{i t-1}^{*}$.

The instrument thus obtained is well and positively correlated to the change in the cost of labour and the regression of the change in labour cost on the exogenous variables and the instrument provides a positive coefficient, which is highly significant for the instrument. 
exogenous variations of the RTC scheme stemming from the 2004, 2006 and 2008 reforms (Box 3).

The parameters of the fixed effect autoregressive model can be estimated by focusing on the change in the endogenous variable between two dates and using the lagged explanatory variables as an instrument: the aim is to control the endogeneity linked to the autoregressive term (Arellano \& Bond, 1991). However, the coefficient $\rho$ is particularly high and the employment change over the course of a year is barely correlated with the change during the following year. The instruments commonly used are thus weak, undermining the quality of the estimation. We prefer to use the solution proposed by Blundell and Bond (1998): based on an assumption of stationarity of the initial population of firms, they estimate a labour demand model using the lagged change in employment as an instrument of the lagged employment level ${ }^{20}$.

Finally, to estimate the model, firms are also assumed to be faced with constrained demand: they cannot decide directly the level of their turnover, regarded as exogenous in the short term. This assumption is partially justified by the modest size of the firms under consideration.

The estimation is made using the generalised method of moments: the orthogonality assumptions apply to the residual terms $\mu_{i}+\varepsilon_{i t}$ (for the lagged employment change, the turnover change and the instrumental variable) and to the residual changes $\varepsilon_{i t}-\varepsilon_{i t-1}$ (for the same variables, except the lagged employment change).

20. On average, over the years and across the sectors, the correlation between the change in employment over a year and the change over the following year is slightly negative (-6\%). The correlation between the lagged employment change and the employment level is higher and positive (+27\%).

Box 4

\section{METHOD FOR ESTIMATING THE EFFECT OF R\&D PUBLIC SUPPORT ON EMPLOYMENT}

The effect of R\&D public support on highly qualified labour is calculated in two stages.

Stage 1: Calculation of the change in employment levels for fixed labour cost and turnover

The labour demand model (1) enables us to estimate, using the recurrence method, the logarithm of employment levels using an initial employment value (on date $t_{0}$ ), and of the change in the turnover and the cost of labour:

$$
\begin{aligned}
\hat{l}_{i t} & =\hat{\rho} \hat{l}_{i t-1}+\hat{\alpha}_{1} y_{i t}+\hat{\alpha}_{2} y_{i t-1}+\hat{\beta} c_{i t}+\hat{\mu}_{i}+\hat{\delta}_{t} \\
& =f\left(l_{i t_{0}}, y_{i t_{0}}, \cdots, y_{i t}, c_{i t_{0}+1}, \cdots, c_{i t}, \hat{\mu}_{i}, \hat{\delta}\right)
\end{aligned}
$$

In formula (2), it is possible to separate what depends on the initial value of employment and the fixed effect from what depends on the change in the cost of labour and the turnover:

$$
\begin{aligned}
\hat{l}_{i t} & =g_{t}\left(l_{i t_{0}}, \hat{\mu}_{i}, \hat{\delta}\right)+ \\
& h_{t}\left(y_{i t_{0}}, \cdots, y_{i t}, c_{i t_{0}+1}, \cdots, c_{i t}, \hat{\alpha}_{1}, \hat{\alpha}_{2}, \hat{\beta}\right)
\end{aligned}
$$

For a firm $i$ receiving support at time $T$ (this date is not identical for all firms), being granted support will modify both the cost of labour and the turnover. We can estimate the change in the employment level (between $T-1$ and $t$ ) due to this change in the cost of labour and the turnover by setting these two variables at their value at time $T-1$. This change in the employment level is proportional to:

$$
\begin{aligned}
\Delta_{i t} & =\exp \left(h_{t}\left(y_{i T-1}, \cdots, y_{i t}, c_{i T}, \cdots, c_{i t}\right)\right) \\
& -\exp \left(h_{t}\left(y_{i T-1}, \cdots, y_{i T-1}, c_{i T-1}, \cdots, c_{i T-1}\right)\right)
\end{aligned}
$$

Stage 2: Comparison with firms that have not yet received aid

The previous calculation assumes that, in the absence of the receipt of aid, the turnover would not have changed, which appears to be a particularly strong assumption. Working on the basis of differences between treated and non-treated firms (and therefore on the basis of the difference-in-difference method) enables us to revert to a more realistic scenario by comparing the change measured for a firm $i$ that has received aid with the mean change for firms that did not receive aid during the period between $T$ to $t$ and which have a propensity score close to that of firm $i$ (this mean change is denoted by the exponent $\mathrm{C}$ ). The effect of the aid on firm $i$ is finally estimated as follows:

$$
\operatorname{ATT}(i, t)=\exp \left(\frac{\hat{\sigma}_{t}^{2}}{2}\right) \cdot \exp \left(g_{t}\left(l_{i t_{0}}, \hat{\mu}_{i}, \hat{\delta}\right)\right) \cdot\left(\Delta_{i t}-\Delta_{i t}^{C}\right)
$$

It should be noted that the bias induced by the transition to the exponential is controlled by a correction using an estimation of the standard deviation $\sigma_{t}$ predicted by the labour demand model at time $t$. 


\section{Calculation of the effect of public funding} on highly qualified labour

The effect of public funding on highly qualified labour is estimated using the labour demand model and calculating differences-in-differences. For each firm receiving support, we estimate the change in employment due to changes in the cost and the turnover by setting these two variables at the level achieved in the year preceding the year in which the first aid is received $^{21}$ (Box 4). The labour demand model allows us to decompose this change into two terms: one depending on the fixed effect, time effects and the initial employment level, the other depending on the cost of labour and the turnover. The group of non-treated firms is thus used to control only the change in the second term ${ }^{22}$.

\section{Results}

The estimation of the model of demand for highly qualified labour by small firms having received support at least once and present in 2003 (Table 3) shows that demand in a given year depends greatly on demand in the previous

21. For firms already receiving support in the reference year (2003 or 2007), we use the levels from the reference year, which amounts to estimating the effect of the supplementary aid obtained since this date.

22. Firms that have not yet received any support (at a given date) are divided into 10 groups based on their propensity score. The mean results obtained for each of these groups serve as a reference for changes among firms receiving support. year (the employment coefficients at $t-1$ are fairly high at around 0.8 ) and that firms increase their workforce if their turnover increases and the cost of labour falls. Differences across sectors are fairly limited, except for the labour cost effect: its coefficient is not significantly different from 0 in the IT services sector, whereas it is negative and significant (between - 0.16 and -0.18 ) in the two other sectors.

The effect of the supplementary support received by the firms in the panel relative to the reference year is presented below.

The supplementary aid for $\mathrm{R} \& \mathrm{D}$ relative to 2003 received by the small firms present in 2003 follows a clear upward trend, increasing in constant 2000 Euro - from 1 million in 2004 (last column in Table 4) to 106 million in 2010. According to our estimations, this supplementary aid for R\&D led to an increase of 1,160 FTE highly qualified jobs in 2010 (Table 4, first column). The effect of the supplementary aid on highly qualified employment increases each year: after being close to 0 in 2004 and 2005, it increases from 2006 onwards. For each firm receiving aid, the number of jobs likely to have been funded by the supplementary support can be determined by dividing the amount of this aid by the average cost of an R\&D job. Lastly, the effect on the number of highly qualified jobs not financed by aid (or financed by the firms themselves, Table 4, third column) equates to the difference between the effect on highly qualified employment and the number of highly

Table 3

Model of demand for highly qualified labour for small firms having received aid at least once between 2003 and 2010 (equation (1))

\begin{tabular}{|c|c|c|c|}
\hline \multirow[t]{2}{*}{ Variables } & \multicolumn{3}{|c|}{$\begin{array}{c}\text { Estimated coefficients } \\
\text { Sectors }\end{array}$} \\
\hline & Industry & IT services & $\begin{array}{c}\text { Scientific } \\
\text { and technical activities }\end{array}$ \\
\hline Highly qualified employment at $t-1$ (log.) & $0.76^{\star \star \star}$ & $0.86^{\star \star \star}$ & $0.77^{\star \star \star}$ \\
\hline Turnover at $t$ (log.) & $0.08^{\star \star \star}$ & $0.1^{\star \star \star}$ & $0.07^{\star \star \star}$ \\
\hline Turnover at $t-1$ (log.) & $-0.02^{*}$ & $-0.05^{\star \star \star}$ & 0 \\
\hline $\begin{array}{l}\text { Relative mean cost of highly-qualified } \\
\text { employment at } t \text { minus aid (log.) }\end{array}$ & $-0.16^{\star \star *}$ & -0.04 & $-0.18^{\star *}$ \\
\hline
\end{tabular}

Note: model estimated using the generalised method of moments (GMM) and an instrument for labour cost. Employment is measured in full-time equivalent. The coefficients differ significantly from zero for level tests at $10 \%\left({ }^{\star}\right), 5 \%\left({ }^{\star \star}\right)$ and $1 \%\left({ }^{\star \star \star}\right)$. Confidence intervals are obtained by bootstrap.

Reading note: for the industry sectors, the level of highly-qualified employment at time $t$ is explained by the level of highly-qualified employment at time $t-1$ (estimated coefficient of 0.76 ), the turnover in $t$ and $t-1$ and the relative mean cost of highly-qualified labour in relation to the costs of other types of labour. The specification also include controls for each year of observation (estimated coefficients not presented).

Coverage: Small firms on the panel that had highly qualified staff in 2003 and which received aid at least once over the period 2003-2010 (2,261 firms, unbalanced panel).

Source: MENESR, GECIR database and R\&D Survey; Acoss, JEl database, Lifi, Ficus/Ésane, DADS, authors' calculations. 
Table 4

Estimated effect of the supplementary R\&D aid obtained by small firms in reference to 2003 on total highly qualified employment and comparison with the supplementary aid received

\begin{tabular}{|c|c|c|c|c|c|c|}
\hline & $\begin{array}{c}\text { Effect } \\
\text { on highly } \\
\text { qualified } \\
\text { employment }\end{array}$ & $\begin{array}{c}\text { Effect } \\
\text { on R\&D } \\
\text { employment }\end{array}$ & $\begin{array}{l}\text { Effect on highly } \\
\text { qualified } \\
\text { employment } \\
\text { not financed by aid }\end{array}$ & $\begin{array}{l}\text { Effect on R\&D } \\
\text { employment not } \\
\text { financed by aid }\end{array}$ & $\begin{array}{l}\text { Effect on R\&D } \\
\text { employment not } \\
\text { financed by aid } \\
\text { excluding 'RTC } \\
\text { operating expenditure' }\end{array}$ & $\begin{array}{l}\text { Supplementary aid } \\
\text { in reference to } 2003 \\
\text { (in millions of } \\
\text { constant } 2000 \text { Euro) }\end{array}$ \\
\hline 2004 & -20 & $-20^{*}$ & 10 & 10 & $-90^{*}$ & 1 \\
\hline 2005 & 40 & 10 & $-270^{\star \star}$ & $-290^{\star \star \star}$ & $-290^{\star \star \star}$ & 18 \\
\hline 2006 & $140^{\star *}$ & $100^{*}$ & $-180^{*}$ & $-220^{\star \star \star}$ & $-190^{\star \star \star}$ & 22 \\
\hline 2007 & $340^{\star \star \star}$ & $240^{\star *}$ & -120 & $-220^{\star \star}$ & $-150^{\star \star}$ & 32 \\
\hline 2008 & $530^{\star \star \star}$ & $370^{\star \star \star}$ & $-700^{\star \star \star}$ & $-860^{\star \star \star}$ & $-520^{\star \star \star}$ & 86 \\
\hline 2009 & $810^{\star \star \star}$ & $570^{\star \star \star}$ & $-400^{\star \star}$ & $-640^{\star \star \star}$ & $-220^{\star}$ & 93 \\
\hline 2010 & $1160^{* \star *}$ & $810^{\star \star \star}$ & -140 & $-480^{\star \star \star}$ & -30 & 106 \\
\hline
\end{tabular}

Note: effects in full-time equivalent employment (FTE); supplementary aid in millions of constant 2000 Euro. The results differ significantly from zero for level tests at $10 \%\left(^{\star}\right), 5 \%\left(^{(*}\right)$ and $1 \%\left(^{\star \star *}\right)$. These tests are obtained through bootstrap.

Reading note: in relation to 2003, the supplementary aid received in 2005 amounted to 18 million Euro (column 6). The effect of this supplementary aid on highly qualified employment is estimated at +40 FTE posts in 2005 (column 1) and +10 FTE posts for R\&D employment (column 2). The effect on employment not financed by aid is an estimated fall of 270 FTE posts for highly qualified employment (column 3), 290 FTE posts for R\&D posts (column 4) and 290 FTE posts if the 'RTC operating expenditure' is not counted as aid (column 5). Coverage: small firms on the panel that had highly qualified staff in 2003 and which received aid at least once over the period 2003-2010 (2,261 firms, unbalanced panel).

Source: MENESR, GECIR database and R\&D Survey; Acoss, JEl database; Insee, Lifi, Ficus/Ésane, DADS, authors' calculations.

qualified jobs likely to have been financed by the supplementary aid: it is significant and negative, except in 2004, 2007 and 2010. In 2010, the estimated effect on highly qualified employment not financed through aid improves, but remains negative; the estimation also becomes more imprecise and, in the end, not significant.

Only some of the highly qualified jobs are really R\&D jobs: to estimate how many (second column), we once again make an assumption that, for each sector and category of company, the ratio of the number of $R \& D$ jobs to the number of highly qualified jobs is equal to that estimated for the period 2008 to 2010 . Based on this assumption, the deficit in terms of R\&D jobs not financed through support (fourth column) is 220 FTE jobs in 2006 (compared to 180 FTE highly qualified jobs). As with highly qualified employment, we observe clearly more negative effects as of the 2008 reform of the RTC; moreover, they are significant and negative, except in 2004 .

At last, adding together the estimations obtained in the various years for the firms present in 2003 , only $63 \%{ }^{23}$ of the supplementary aid paid out between 2004 and 2010 would have served to finance new highly qualified jobs ( $44 \%$ if we only take into consideration $R \& D$ jobs).

23. This result is based on a $95 \%$ confidence interval $[42 \% ; 84 \%]$
This evaluation is based on an increase in employment aid, due to the fact that the share of the RTC linked to operating costs is taken into account $^{24}$. If we assume that this part of the RTC is not taken into account, the number of R\&D jobs financed by the firms themselves falls by 30 FTE jobs only (a change not significantly different from zero) in 2010 (fifth column in Table 4) instead of 480 FTE jobs (fourth column) and $58 \%$ of the supplementary support paid out between 2004 and 2010 would have served to finance new R\&D jobs.

The results above were established for firms present in 2003. In order to measure the effect of the aid on more firms, we now focus on firms present in 2007. This new estimation enables us to better take account of the reform of the RTC in 2008. The total aid received by these firms was (in constant 2000 Euro) 344 million in 2010, whereas it was only 135 million for the earlier group (the supplementary support received in 2010 increases from 106 million compared to the reference year 2003 (last column Table 4) to 171 million compared to the year 2007 (last column in Table 5). For this expanded group of firms, the effect on the employment level of highly qualified staff of the supplementary support is at its maximum in 2010 with 830 FTE jobs (column 1); in parallel, the supplementary aid received that year equates

24. They are set at $75 \%$ of $R \& D$ staff expenditure (see above) Not taking it into account would reduce the amounts of the RTC used to finance employment by $43 \%$. 
to financing 2,140 FTE jobs, which equates to a fall of 1,310 FTE highly-qualified jobs not financed by aid (column 3). For R\&D-related employment, there is a bigger fall of 1,520 FTE jobs financed by the firms themselves. These falls are statistically significant for all years. This is also the case if we do not take account of the part of the RTC linked to operating expenditure (column 5). Lastly, among firms present in 2007, only $24 \%$ (between 18 and $34 \%$ based on the $95 \%$ confidence interval) of the supplementary aid paid out between 2008 and 2010 compared to 2007 served to finance new highly qualified jobs $(19 \%$ if we only consider R\&D-related jobs and $29 \%$ if we do not take account of the RTC linked to operating expenditure).

The detailed results by sector of activity show that the fall in the employment of highly qualified staff financed by the firms themselves applies to all sectors, but was greater in the industrial sector and more moderate in the scientific and technical sectors (see online complement C5, Tables C5-1 and C5-2). For the firms present in 2007, only $9 \%$ of the supplementary support received by firms from the industrial sector served to finance new highly-qualified jobs compared to $15 \%$ for IT service firms and $43 \%{ }^{25}$ for firms in the scientific and technical activities sector.

\section{Discussion of the results and their robustness}

In this section, we discuss the assumptions used to construct the control group and estimate the

25. The 95\% confidence intervals are respectively for each sector $[6 \% ; 21 \%]$, [6\%;24\%], and [31\%;61\%]. model and their influence on the results of the evaluation.

For the two populations of firms studied (present in 2003 or in 2007), we observe an increase in the effect of support on the employment of highly qualified staff at the end of the period. This effect is, in part, linked to the lower quality of the control group in $2010^{26}$, which may have led to an overestimation of the effect of the aid in the latter years.

The coverage of Tables 4 and 5 only includes firms belonging to the 75 most R\&D-intensive sectors and which had one or more highly qualified employee in 2003 or 2007. These two restrictions enable better quality counterfactuals to be found. However, these restrictions are more technical than actually reflecting economic reality and it seems reasonable to expand the estimations to include a broader coverage comprising all VSBs and other small SMEs.

The effect of R\&D support is estimated by comparing firms receiving support with firms not receiving aid without taking account of a possible effect of the aid on firms' survival. If R\&D support enabled the firms to prolong their activity (or to retain their highly-qualified employees), the effect of the aid would have been underestimated. However, a comparison of the firms from the panel receiving support prior to 2004 and the firms having similar propensity scores that have never received aid indicates that the firms receiving aid are observed for a

26. It only includes firms that have never received support, which constitute a lower quality counterfactual than firms that have not yet received aid (online complement C4).

\section{Table 5}

Estimation of the effect of the supplementary aid obtained by small firms in reference to 2003, on total highly qualified employment and comparison with the supplementary aid received

\begin{tabular}{|c|c|c|c|c|c|c|}
\hline & $\begin{array}{c}\text { Effect on } \\
\text { highly } \\
\text { qualified } \\
\text { employment }\end{array}$ & $\begin{array}{c}\text { Effect on } \\
\text { R\&D } \\
\text { employment }\end{array}$ & $\begin{array}{c}\text { Effect on highly } \\
\text { qualified } \\
\text { employment } \\
\text { not financed by aid }\end{array}$ & $\begin{array}{c}\text { Effect on R\&D } \\
\text { employment } \\
\text { not financed by aid }\end{array}$ & $\begin{array}{c}\text { Effect on R\&D employ- } \\
\text { ment not financed by } \\
\text { aid excluding 'RTC } \\
\text { operating expenditure' }\end{array}$ & $\begin{array}{c}\text { Supplementary aid } \\
\text { in relation to 2007 } \\
\text { (in millions of } \\
\text { constant 2000 Euro) }\end{array}$ \\
\hline 2008 & $210^{\star \star}$ & $160^{\star \star}$ & $-1,710^{\star \star \star}$ & $-1,760^{\star \star \star}$ & $-1,150^{\star \star \star}$ & 131 \\
2009 & $440^{\star \star *}$ & $360^{\star \star *}$ & $-1,660^{\star \star *}$ & $-1,740^{\star \star *}$ & $-980^{\star \star *}$ & 151 \\
2010 & $830^{\star \star *}$ & $620^{\star \star *}$ & $-1,310^{\star \star *}$ & $-1,520^{\star \star *}$ & $-720^{\star \star *}$ & 171 \\
\hline
\end{tabular}

Note: effects in full-time equivalent employment (FTE); supplementary aid in millions of constant 2000 Euro. The results differ significantly from zero for level tests at $10 \%\left(^{\star}\right), 5 \%\left(^{(\star)}\right)$ and $1 \%\left({ }^{\star \star \star}\right)$. These tests are calculated using a bootstrap method

Reading note: in relation to 2007, the supplementary aid received in 2008 amounted to 131 million Euro (column 6). The effect of this supplementary aid on highly qualified employment is estimated at +210 FTE posts in 2008 (column 1) and +160 FTE posts for R\&D employment (column 2). The effect on employment not financed by aid is an estimated fall of 1,710 FTE posts for highly qualified employment (column 3), 1,760 FTE posts for R\&D employment (column 4) and 1,150 FTE posts if the 'RTC operating expenditure' is not counted as aid (column 5).

Coverage: small firms on the panel that had highly qualified employees in 2007 and which received aid at least once over the period 2007-2010 (4,117 firms, unbalanced panel).

Source: MENESR, GECIR database and R\&D Survey; Acoss, JEl database, Insee, Lifi, Ficus/Ésane, authors' calculations. 
slightly longer period, but that the 'survival' gap between the two groups is not statistically significant (online complement C5, Table C5-4).

To define the control group, we do not have exhaustive information about direct support: the control group may contain some firms that have received subsidies. This problem can lead to underestimating the effect of aid, as the change in the employment levels of the firms not receiving aid has perhaps been overestimated. This bias should, however, decrease as use of the RTC increases, since the subsidised firms are increasingly registered in the Gecir database.

The firms in the control group that have never received aid are selected based on observable characteristics that determine their propensity score. However, unobserved variables could have influenced both the participation of firms in aid mechanisms and their demand for highly qualified labour: not taking them into account could have biased our estimations. However, among these unobserved variables, the cost of seeking aid is significantly higher for small firms than for large firms (Arqué-Castells et Mohnen, 2015) and knowledge of the support schemes probably depends on the age of the firms: these variables are thus partially controlled with the propensity score, which takes account of various characteristics relating to firms' size and age.

In the model of demand for highly qualified labour, support is equated to an immediate reduction in the cost of labour. While the subsidies and reductions in employer payroll taxes provided under the JEI scheme are actually received by the firms as soon as the R\&D expenditure is made, this is not the case with the RTC, especially for firms that do not declare any corporation tax: these firms hold a receivable, which sometimes only has to be reimbursed in full by the State after 3 years. However, since 2007, derogations have allowed small and young enterprises $^{27}$ to secure the reimbursement of the RTC receivables as early as the following year, which enhances the credibility of the assumption used for the labour demand model.

27. To be more precise, derogations were granted to dynamic JEls and SMEs in 2007 and 2008, to all companies in 2009, and only to SMEs from 2010 onwards.
The results presented may be partially biased, as MENESR-accredited firms may belong to the control group. These may be firms classified in the R\&D-intensive sectors, which, though still not having received any aid $^{28}$, benefit indirectly from the RTC received by their clients. However, if we exclude all the accredited firms from the coverage of the study, we obtain results that are very close to those presented in Tables 4 and 5 (online complement C5, Tables C5-5 and C5-6).

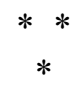

The econometric analyses conducted (using the difference-in-difference method and a labour demand model combined with a matching model) confirm the crowding-out effect suggested by the aggregated analysis: they show that the effect of R\&D public support on expenditure on highly qualified staff and highly qualified $R \& D$ staff has been positive, but well below the increase in the aid received, especially from 2008 onwards. It would appear that the very strong increase in the rates of R\&D support during the 2000s did not lead to effectively increasing the employment of R\&D staff in small firms. This result differs starkly from those obtained up until present in most of the empirical research based on French data. The result is obtained from a coverage including the VSBs, which are usually disregarded in research conducted on the basis of the data from the R\&D Survey.

However, it should be noted that our results are interpretable essentially over the short term and not as an indication of long-term effects of R\&D public funding. Lastly, this study does not take account of recent changes in the rules used to calculate the RTC. Thus, the reduction in 2010 , followed by the abolition of the increased rates of $50 \%$ and $40 \%$ in $2013^{29}$, which significantly reduced the support rate for small firms, may have mitigated the crowding-out effect highlighted in this study.

28. A very large majority of the accredited companies within the coverage of the study have, however, received aid at least once (75\% of the VSBs and $87 \%$ of the other SMEs that were accredited in 2010 received aid between 2005 and 2010).

29. It should also be noted that the operating expenditure base was lowered in 2011 (from 75\% to 50\% for staff expenditure). 


\section{BIBLIOGRAPHY}

Acemoglu, D., Akcigit, U., Bloom, N. \& Kerr, W. R. (2013). Innovation, Reallocation and Growth. NBER Working Paper 18993.

Aghion, P., Askenazy, P., Berman, N., Cette, G. \& L. Eymard (2012). Credit Constraints And The Cyclicality Of R\&D Investment: Evidence From France, Journal of the European Economic Association, 10(5), 1001-1024.

Akcigit, U. \& Kerr, R. W. (2010). Growth Through Heterogeneous Innovations. NBER Working Paper 16443.

Arellano, M. \& Bond, S. (1991). Some tests of specification for panel data: Monte Carlo evidence and an application to employment equation. Review of Economic Studies, 58(2), 277-297.

Arqué-Castells, P. \& P. Mohnen (2015). Sunk costs, extensive R\&D subsidies and permanent inducement effects. Journal of Industrial Economics, 63(3), 458-494.

Baghana, R. \& Mohnen, P. (2009). Effectiveness of R\&D tax incentives in small and large enterprises in Québec. Small Business Economics, 33(1), 91-107.

Béguin, J.-M., Hecquet, V. \& Lemasson, J. (2012). Un tissu productif plus concentré qu'il ne semblait. Insee Première $\mathrm{N}^{\circ} 1399$.

Bellégo, C. \& Dortet-Bernadet, V. (2014). L'impact de la participation aux pôles de compétitivité sur les PME et les ETI. Économie et Statistique, 471, 65-83.

Bloom, N., Schankerman, M. \& Van Reenen, J. (2013). Identifying technology spillovers and market rivalry. Econometrica, 81(4), 1347-1393.

Blundell, R. \& Bond, S. (1998). Initial conditions and moment restrictions in dynamic panel data models. Journal of Econometrics, 87(1), 115-143.

Bozio, A., Irac, D. \& Py, L. (2014). Impact of research tax credit on R\&D and innovation: evidence from the 2008 French reform. Banque de France, Document de travail, 532.

Bresson, G., Kramarz, F. \& Sevestre, P. (1992). Dynamic labour demand Models. In: L. Matyas and P. Sevestre (Eds), The Econometrics of Panel Data: Theory and Applications, pp. 360-387. Kluwer Academic Publishers.
Bronzini, R. \& Iachini, E. (2014). Are incentives for R\&D effective? Evidence from a regression discontinuity approach. American Economic Journal : Economic Policy, 6(4), 100-134.

Busom I., Corchuelo B. \& Martínez-Ros E. (2014). Tax incentives... or subsidies for business R\&D? Small Business Economics, 43(3), 571-596.

Cinceraa, M. \& Veugelers, R. (2013). Young leading innovators and the EU's R\&D intensity gap. Economics of Innovation and New Technology, 22(2), 177-198.

Corchuelo, B. \& Martinez-Ros, E. (2009). The Effects of Fiscal Incentives for R\&D in Spain. Business Economics Working Papers wb092302.

Cottet, V., Quantin, S. \& Régnier, V. (2012). Coût du travail et allègements de charges : une estimation au niveau établissement de 1996 à 2008. Insee, Document de travail G2012/12.

David, P. A., Hall, B. H. \& Toole, A. A. (2000). Is Public R\&D a complement or substitute for private $R \& D$ ? A review of the econometric evidence. Research Policy, 29(4-5), 497-529.

Dortet-Bernadet, V. \& Sicsic, M. (2015). Effet des aides publiques sur l'emploi en R\&D dans les petites entreprises. Insee, Document de travail G2015/11.

Dufau, M. (2017). Les pôles de compétitivité, qui rassemblent les acteurs de l'innovation dans les territoires, comportent une proportion importante de jeunes entreprises. DGE, Le 4 pages de la DGE $\mathrm{N}^{\circ} 67$.

Duguet, E. (2012). The effect of the incremental $R \& D$ tax credit on the private funding of $R \& D$ an econometric evaluation on french firm level data. Revue d'économie politique, 122(3), 405-435.

Duguet, E. (2004). Are R\&D subsidies a substitute or a complement to privately funded $R \& D$ ? Revue d'économie politique, 114(2), 245-274.

Garcia-Macia, D., Hsieh, C.-T. \& Klenow, P. J. (2016). How Destructive is Innovation? NBER Working Paper 22953.

González, X., Jaumandreu, J. \& Pazó, X. (2005). Barriers to innovation and subsidy effectiveness. Rand Journal of Economics, 36(4), 930-950. 
Griffith, R., Redding, S. \& Van Reenen, J. (2003). R\&D and Absorptive Capacity: Theory and Empirical Evidence. The Scandinavian Journal of Economics, 105(1), 99-118.

(2004). Mapping the Two Faces of R\&D: Productivity Growth in a Panel of OECD Industries. The Review of Economics and Statistics, 86(4), 883-895.

Hægeland, T. \& Møen, J. (2007). Input additionality in the Norwegian R\&D tax credit scheme. Statistics Norway, report 47.

Ientile, D. \& Mairesse, J. (2009). A policy to boost R\&D: Does the R\&D tax credit work? European Investment Bank Papers 6/2009.

Jones, I. C. \& Williams, C. J. (1998). Measuring the social return to R\&D. The Quarterly Journal of Economics, 113(4), 1119-1135.

Köhler, C., Larédo, P. \& Rammer, C. (2012). The impact and effectiveness of fiscal Incentives for R\&D - compendium of evidence of the effectiveness of innovation policy intervention. Manchester Institute of Innovation Reseach and NESTA.

Lelarge, C. (2009). Soutenir l'effort de R\&D des structures entrepreneuriales. Analyse de deux dispositifs ciblés récents. Thèse, Université Paris X Nanterre.

Lhuillery, S., Marino, M. \& Parrotta, P. (2013). Évaluation de l'impact des aides directes et indirectes à la R\&D en France. Rapport pour le MENESR.

Lokshin, B. \& Mohnen, P. (2012). How effective are level-based R\&D tax credits? Evidence from the Netherlands. Applied Economics, 44(12), $1527-1538$.
Lokshin, B. \& Mohnen, P. (2013). Do R\&D tax incentives lead to higher wages for R\&D workers? Evidence from The Netherlands. Research Policy, 42(3), 823-830.

MENESR (2014). Développement et impact du crédit d'impôt recherche : 1983-2011. Rapport du MENESR.

Mulkay, B. \& Mairesse, J. (2013) The R\&D Tax Credit in France: Assessment and Ex-Ante Evaluation of the 2008 Reform. Oxford Economic Papers, vol 65(3), 746-766

OCDE (2016). Incitations fiscales à la recherche-développement. In : OCDE (Ed.), Science, technologie et industrie : Tableau de bord de l'OCDE 2015. «L'innovation au service de la croissance et de la société ». pp. 172-187. Paris: OCDE.

OCDE (2017). Statistiques de la recherche et développement.

http://www.oecd.org/fr/sti/inno/srd.htm

Schneider, C. \& Veugelers, R. (2010). On young highly innovative companies: why they matter and how (not) to policy support them. Industrial and Corporate Change, 19(4), 969-1007.

Serrano-Velarde, N. (2008). How Do Firms React to R\&D Subsidies? Evidence from regression discontinuity design. mimeo.

https://www.insee.fr/fr/statistiques/2017510? sommaire $=2017528$

Zuñiga-Vicente, J. A., Alonso-Borrego, C., Forcadell, F. J. \& Galán, J. I. (2014). Assessing the effect of public subsidies on firm R\&D investment: A survey. Journal of Economic Surveys, 28, $36-67$. 